\title{
Proceeding
}

Supplementary Issue: Spring Conferences of Sports Science. 15th Convention and Workshop of the International Network of Sport and Health Science, 5-8 June 2019. University of Las Palmas de Gran Canaria, Las Palmas de Gran Canaria, Spain.

\section{1 versus 1 in football after 20 years}

\author{
TOMMASO TROCCHIA ${ }^{1}$, ANNA MARIA MARIANI ${ }^{2}$, SALVATORE PIGNATO ${ }^{3}$, FRANCESCA D'ELIA ${ }^{1}$ \\ ${ }^{1}$ University of Salerno, Italy \\ 2University Niccolò Cusano of Rome, Italy \\ 3University Kore of Enna, Italy
}

\begin{abstract}
The new millennium was marked by the epic of the legendary Barcelona of Guardiola, the coach who revolutionized the world of football with his tiki taka. This game is made of fast ball exchanges, continuous changes of position and search for the free space to occupy but it has downgraded the dribbling, that is one of the main technical skills of the game of football. Starting from football schools, it almost seems that 1vs1 has been set aside to favour other fundamental techniques, so we find ourselves in a period where fewer and fewer players take the responsibility to try a bet in $1 \mathrm{v} 1$, but prefer to pass the ball to the closest mate. This research has analysed the goals of final stages of two World cup (the most football event), 20 years later, Russian 2018 and France 1998 and has demonstrated that in 20 years, the incidence of goals scored after a dribble influenced by the action has decreased of $10 \%$. From the round of 16 onwards of Russian 2018 have been scored 47 goals, whose 8 after an influential dribbling (17\%). In France 1998 have been scored 45 goals, 12 with an influential dribbling (27\%). The world of football should be open to new revolutions, without ignore none of basic skills to a player's growth. Keywords: Performance analysis; Match analysis; Video analysis; Gol.
\end{abstract}

\section{Cite this article as:}

Trocchia, T., Mariani, A.M., Pignato, S., \& D'Elia, F. (2019). 1 versus 1 in football after 20 years. Journal of Human Sport and Exercise, 14(4proc), S686-S690.

doi:https://doi.org/10.14198//hse.2019.14.Proc4.28

Corresponding author. University of Salerno, Italy.

E-mail: tommasotrocchia@hotmail.com

Supplementary Issue: Spring Conferences of Sports Science. 15th Convention and Workshop of the International Network of Sport and Health Science, 5-8 June 2019. University of Las Palmas de Gran Canaria, Las Palmas de Gran Canaria, Spain. JOURNAL OF HUMAN SPORT \& EXERCISE ISSN 1988-5202

(c) Faculty of Education. University of Alicante

doi:10.14198/jhse.2019.14.Proc4.28

S686 $|2019|$ Proc4 | VOLUME 14

C 2019 University of Alicante 


\section{INTRODUCTION}

Soccer is sports game of whom the performance has the complex factors, first of all quantitative one (Altavilla et al, 2019, Altavilla et al, 2017, D'Elia et al, D'Isanto et al, 2019, Rago et al, 2017, Raiola, D'Isanto, 2016). One of fundamentals football's skill is the dribbling that is highlighting by motor control theories (Polidoro et al, 2013, Raiola, 2017, Raiola, Di Tore, 2017, Severino et al, 2019). Have in a team football players that can dribble is very important for create free spaces, gain numerical superiority and disorder the opponent's defences (Giordano et al, 2019, Izzo et al, 2018), but, started to youth football academy, the $1 \mathrm{vs} 1$ has been set aside to favour other fundamental techniques so we find ourselves in a period where fewer and fewer players take the responsibility to try a bet in 1v1, but prefer to pass the ball to the closest mate (Strauss et al, 2019, Ceruso et al 2019). This is attributable to ascent in the last decade of the tiki taka, also called position game. Consequently, they are almost extinct the best football player talent that grinded space and dribbled any football player in the field, to leave room a football player that are gears in a fixed and tested gaming system (Altavilla et al, 2017). The pioneer of this type of game is Pep Guardiola, that with his Barcelona, from 2008 to 2012 won: 3 Spanish Liga, 2 king's cup, 3 Spanish supercups, 2 champions league, 2 UEFA supercups and 2 World cups for clubs. Tiki taka provides an obsessive possession of the ball and has the purpose of keeping the ball as long as possible, tiring the opponent's defence, and then finalizing through a rapid verticalization (Alonso-Gonzalez et al, 2017, Hills et al, 20019, Gomez et al, 2018). Often the opposite teams against this game system can't reach $30 \%$ of ball's possession and even the conquest of a simple corner kick is difficult to achieve. Aim study is to carry out the evolution of dribble evidences. The study have to demonstrate how is changed, in 20 years, the incidence of goals scored after a dribble influenced by the action has changed, here is how to refer to that most important football competition at international level: the World Cup.

\section{METHODS}

All the games, from the round of 16 onwards from Russia 2018 to France 1998 World Cups were analysed by video. I have been taken into consideration all the actions have been present an influential dribbling for the purposes of the action, regardless which is been or not a goal, to understand if the percentage of goals scored after an influential dribbling for the action has decreased after 20 years.

I used a t-test to understand if there is a greater incidence due to the expansion of the tiki taka and therefore to less dribbling training.

\section{RESULT}

As following, it can see the Figure 1 the differences between Russia and France.

Table 1. Test-t: difference between dribbling performed with and without goals (1998-2018)

\begin{tabular}{|c|c|c|c|c|c|c|c|c|}
\hline & \multicolumn{5}{|c|}{ Paired differences } & \multirow{3}{*}{$t$} & \multirow{3}{*}{ gl } & \multirow{3}{*}{$\begin{array}{l}\text { Sign. (with } \\
\text { two tails) }\end{array}$} \\
\hline & \multirow[t]{2}{*}{ Media } & \multirow{2}{*}{$\begin{array}{l}\text { Std. } \\
\text { Deviation }\end{array}$} & \multirow{2}{*}{$\begin{array}{l}\text { Average } \\
\text { standard } \\
\text { error }\end{array}$} & \multicolumn{2}{|c|}{$\begin{array}{l}\text { 95\% Confidence interval } \\
\text { difference }\end{array}$} & & & \\
\hline & & & & Lower & Higher & & & \\
\hline $\begin{array}{c}\text { VAR00001 } \\
- \\
\text { VAR00002 }\end{array}$ & \#\#\#\# & 1.32858 & .23486 & -.57275 & .38525 & -.399 & 31 & .693 \\
\hline
\end{tabular}




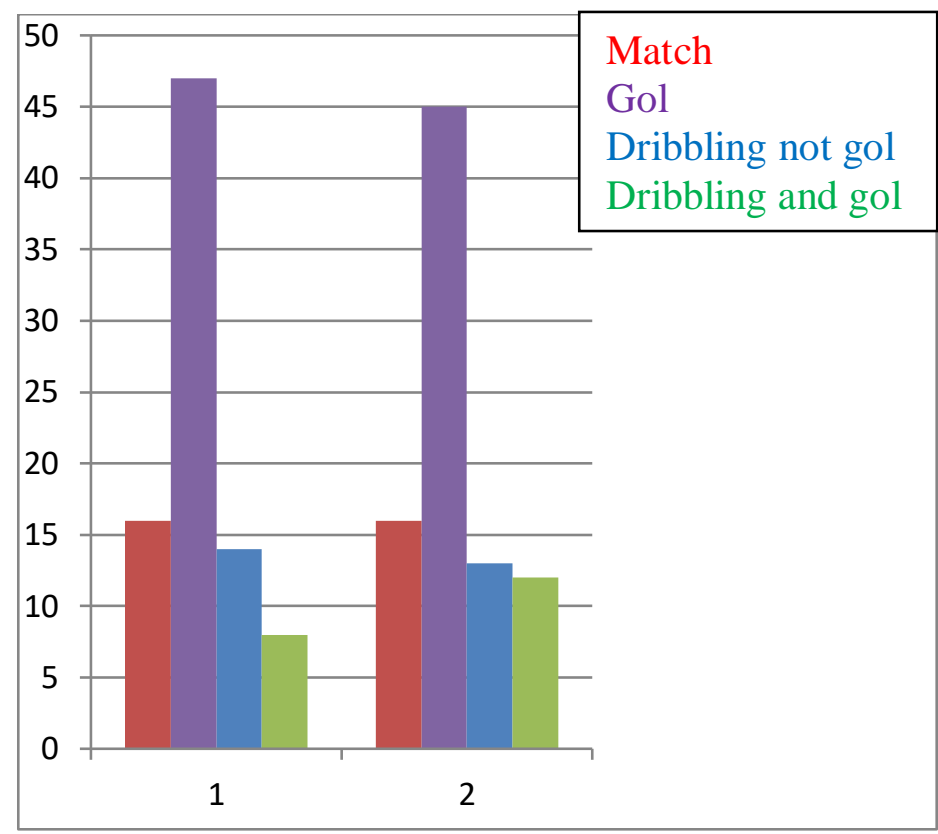

Figure 1. 1) Russia 2018 and 2) France 1998

\section{DISCUSSION}

From Figure no. 1 it can see how, with the same number of matches, in 2018, 2 goals were scored more than in 1998 (47 to 45), but the quality is changed. In 2018 out of 47 goals just 8 were scored after an influential dribbling (around 17\%), while in 1998 out of 45 there were 12 goals scored after a dribble (about 27\%). As for the total shares with the presence of an influential dribbling for the purposes of the action, in 2018 we had 22 shares, of which, as mentioned, 8 were finalized in goals (36\%). In 1998 they were 25 , with 12 goals in goals (48\%).

From table no. 1 , on the other hand, it can be seen that the 0.693 result does not represent a significant difference between the two dribbling series with and without goals made in 1998 and 2018. To be significant, the difference must be $p<0.05$.

\section{CONCLUSION}

Even if the percentage of goals scored after a dribbling is a little higher in 1998 than in 2018, analysing the result, it cannot be said, at least from the few games analysed, that there is an influence for the actions concluded on goal and realized, due to the game system, based mainly on the passages, compared to the use of dribbling. Therefore, to have a certain and definitive result it will be necessary to analyse many more tenders, in the time frame taken into consideration.

This will be our next goal for further study in the near future.

\section{REFERENCES}

Alonso-Gonzalez, A., Alamo-Hernandez, P., Peris-Ortiz, M. Guardiola, mourinho and del bosque: Three different leadership and personal branding styles (2017) Sports Management as an Emerging 
Economic Activity: Trends and Best Practices, pp. 329-344. https://doi.org/10.1007/978-3-319$\underline{63907-920}$

Altavilla, G., Mazzeo, F., D'Elia, F., Raiola, G. (2018) Physical commitment and specific work for each role in an elite soccer team, Journal of Physical Education and Sport, 18 (2), art. no. 83, pp. 570 574.

Altavilla, G., Riela, L., Di Tore, A.P., Raiola, G. (2017) The physical effort required from professional football players in different playing positions. Journal of Physical Education and Sport, 17 (3), art. no. 200, pp. 2007-2012.

Altavilla, G., Di Tore, P.A., Riela, L., D'Isanto, T. (2017) Anthropometric, physiological and performance aspects that differentiate male athletes from females and practical consequences, Journal of Physical Education and Sport, 17, art. no. 226, pp. 2183-2187.

D'Isanto, T., D'Elia, F., Raiola, G., Altavilla, G. (2019) Assessment of sport performance: Theoretical aspects and practical indications, Sport Mont, 17 (1), pp. 79-82.

Ceruso, R., Esposito, G., Federici, A., Valentini, M., D'isanto, T., Preliminary work about the basis data for monitoring youth soccer team planning training (2019) Journal of Human Sport and Exercise, 14 (Proc2), pp. S251-S257. https://doi.org/10.14198/hihse.2019.14.proc2.14

Polidoro, L., Bianchi, F., Di Tore, P.A., Raiola, G. (2013) Futsal training by videoanalysis, Journal of Human Sport and Exercise, 8 (2), pp. 290-296. https://doi.org/10.4100/ihse.2012.8.proc2.31

D'Elia, F., D'Isanto, T., \& Altavilla, G. (2019). Training and performance in the transition period. Journal of Human Sport and Exercise, 14(2proc), S258-S262. https://doi.org/10.14198/ihse.2019.14.Proc2.15

Giordano, L., Federici, A., Valentini, M., D'elia, F. (2019) Dribbling in football: Confronting learning theories, Journal of Human Sport and Exercise, 14 (Proc2), pp. S228-S232. https://doi.org/10.14198/ihse.2019.14.proc2.10

Hills, S.P., Barrett, S., Feltbower, R.G., Barwood, M.J., Radcliffe, J.N., Cooke, C.B., Kilduff, L.P., Cook, C.J., Russell, M. A match-day analysis of the movement profiles of substitutes from a professional soccer club before and after pitch-entry (2019) PLoS ONE, 14 (1). https://doi.org/10.1371/journal.pone.0211563

Gómez, M.-Á., Mitrotasios, M., Armatas, V., Lago-Peñas, C. Analysis of playing styles according to team quality and match location in Greek professional soccer (2018) International Journal of Performance Analysis in Sport, 18 (6), pp. 986-997. https://doi.org/10.1080/24748668.2018.1539382

Izzo, R., Sopranzetti, S., Hosseini Varde'l, C., Molitierno, G. (2018) Video tracking for the detection of external load to establish proper parameters in elite soccer players during high intensity training, Journal of Physical Education and Sport, 18, art. no. 178, pp. 1199-1202.

Raiola, G., D'isanto, T. (2016) Assessment of periodization training in soccer, Journal of Human Sport and Exercise, 11 (Proc1), pp. S267-S278. https://doi.org/10.14198/ihse.2016.11.proc1.19

Raiola, G. (2017) Motor learning and teaching method, Journal of Physical Education and Sport, 17, art. no. 236, pp. 2239-2243. https://doi.org/10.14198/ihse.2016.11.proc1.19

Raiola, G. (2017) Motor learning and teaching method, Journal of Physical Education and Sport, 17, art. no. 236, pp. 2239-2243.

Raiola, G., Di Tore, P.A. (2017) Motor learning in sports science: Different theoretical frameworks for different teaching methods, Sport Science, 10, pp. 50-56.

Rago, V., Pizzuto, F., Raiola, G. (2017) Relationship between intermittent endurance capacity and match performance according to the playing position in sub-19 professional male football players: Preliminary results, Journal of Physical Education and Sport, 17 (2), pp. 688-691. 
Raiola, G. (2014) Motor control and learning skills according to cognitive and ecological dynamic approach in a vision on behaviorism, cognitive, Gestalt and phenomenology theories, Mediterranean Journal of Social Sciences, 5 (15), pp. 504-506. https://doi.org/10.5901/mjss.2014.v5n15p504

Severino, N.C., Cassese, F.P., Ceciliani, A., D'elia, F., Di Tore, A.P. (2019) Psychophysical benefits of recreational five-a-side football, Journal of Human Sport and Exercise, 14 (Proc2), pp. S206-S214. https://doi.org/10.14198/ihse.2019.14.proc2.07

Strauss, A., Sparks, M., Pienaar, C. The use of GPS analysis to quantify the internal and external match demands of semi-elite level female soccer players during a tournament (2019) Journal of Sports Science and Medicine, 18 (1), pp. 73-81.

\section{(c) $(\mathrm{B})(\mathrm{E}$}

This work is licensed under a Attribution-NonCommercial-NoDerivatives 4.0 International (CC BY-NC-ND 4.0). 